\title{
Pemanfaatan Batu Gunung Tambolang Kabupaten Toraja Utara Pada Campuran Laston AC-BC
}

\author{
Gideon Rante ${ }^{\star 1}$, Alpius ${ }^{\star 2}$, Sufiati Bestari ${ }^{\star 3}$ \\ ${ }^{* 1}$ Mahasiswa Program Studi Teknik Sipil, Universitas Kristen Indonesia Paulus, Makassar, Indonesia \\ gideonrante@gmail.com \\ *2 Dosen Program Studi Teknik Sipil, Universitas Kristen Indonesia Paulus, Makassar, Indonesia \\ alpiusnini@gmail.com \\ *3 Dosen Program Studi Teknik Sipil, Universitas Kristen Indonesia Paulus, Makassar, Indonesia \\ sufiati.bestari@gmail.com
}

\begin{abstract}
ABSTRAK
Penelitian ini dilakukan untuk mengetahui nilai karakteristik agregat, rancangan campuran AC-BC, dan nilai stabilitas Marshall sisa rancangan campuran AC-BC melalui pengujian Marshall Konvensional dan Marshall Immersion dengan mengacu pada spesifikasi Umum 2018 (Devisi 6) Kementerian Pekerjaan Umum dan Perumahan Rakyat Republik Indonesia dan Standar Pengujian SNI. Sebelum merancang komposisi untuk pengujian Marshall Konvensional dan pembuatan benda uji uji untuk mendapatkan Stabilitas Marshall sisa, pertama yang dilakukan adalah pengujian karakteristik agregat kasar, agregat halus, dan aspal (filler). Hasil penelitian ini menunjukkan bahwa Material yang berasal dari Gunung Tambolang Toraja Utara memenuhi syarat yang telah ditetapkan dalam spesifikasi Umum Bina Marga 2018. Berdasarkan komposisi pada campuran AC-BC yang menggunakan material dari Gunung Tambolang, yaitu agregat kasar $42,82 \%$, agregat halus $45,73 \%$, bahan pengisi $5,45 \%$, dengan kadar aspal optimum $6 \%$. Setelah dilakukan pengujian Marshall Konvensional maka didapatkan hasil, pengujian memenuhi spesifikasi pada pengujian flow,stabilitas, VMA, VIM dan VFB. Sedangkan stabilitas Marshall sisa dengan menggunakan material dari Gunung Tambolang Kecamatan Toraja Utara memenuhi syarat Spesifikasi Umum Bina Marga 2018, yaitu 96,29\%> 90\%.
\end{abstract}

Kata kunci : Karakteristik agregat, Komposisi AC-BC, Marshall Test

\begin{abstract}
This research was conducted to determine the aggregate characteristic value, the $\mathrm{AC}-\mathrm{BC}$ mixture design, and the Marshall stability value of the remaining AC-BC mixture design through the Conventional Marshall and Marshall Immersion testing with reference to the 2018 General specifications (Division 6) of the Ministry of Public Works and Public Housing of the Republic of Indonesia. and SNI Testing Standards. Before designing the composition for Conventional Marshall testing and making test specimens to obtain residual Marshall stability, the first thing to do is test the characteristics of coarse aggregate, fine aggregate, and asphalt (filler). The results of this study indicate that the material from Mount Tambolang Toraja Utara fulfills the requirements set in the 2018 General Highways specification. Based on the composition of the AC-BC mixture using material from Mount Tambolang, namely coarse aggregate $42.82 \%$, fine aggregate $45,73 \%$, filler material $5.45 \%$, with an optimum aspal content of $6 \%$. After doing the Conventional Marshall test, the results obtained, the test meets the specifications on testing flow, stability, VMA, VIM and VFB. While the remaining Marshall stability using material from Mount Tambolang, North Toraja District, meets the requirements of the 2018 General Bina Marga Specifications, namely $96.29 \%>90 \%$.
\end{abstract}

Keywords: Aggregate Characteristics, AC-BC Composition, Marshall Test

\section{PENDAHULUAN}

Umumnya pembangunan prasarana jalan untuk meningkatkan aksebilitas dan kelancaran perekonomian masyarakat. Dengan adanya jalan raya, perdangan dan pertumbuhan ekonomi dapat ditingkatkan sehingga pembangunan juga meningkat. Dengan ditingkatkannya pembangunan, maka kebutuhan akan material sumber daya alam sangat diperlukan.

Di Kecamatan Rantepao Kabupaten Toraja Utara terdapat Gunung Tambolang yang berpotensi 
Paulus Civil Engineering Journal

Jurnal Teknik Sipil UKI-Paulus Makassar

https://doi.org/10.52722/pcej.v3i2.3214

sebagai suatu material konstruksi perkerasan jalan dan sebagai bahan bangunan.

Supaya mengetahui karakteristik agregat batu Gunung Tambolang perlu dilakukan uji material di laboratorium, selanjutnya direkomendasikan apakah dapat dimanfaatkan sebagai sumber agregat untuk perancangan perkerasan jalan. Penelitian ini bertujuan untuk mengetahui karakteristik material dari Gunung Tambolang, rancangan campuran komposisi campuran, dan pemanfaatannya dalam campuran AC-BC melalui pengujian Marshall konvesional dan Marshall Immersion atau indeks kekuatan sisa.

Perkerasan jalan terdiri atas beberapa lapisan yaitu, Tanah dasar (Subgrade), Lapisan permukaan (Surface Course) dan Lapis Pondasi (Base Course) [1]

Fungsi dari campuran AC-BC adalah untuk menahan beban kendaraan lalu lintas yang paling berat serta mengurangi regangan dari beban kendaraan dan meneruskannya ke lapisan yang ada di bawahnya, maka dari itu campurannya harus memiliki kekakuan yang cukup.

Beton Aspal adalah Perkerasan jalan yang terdiri dari campuran agregat dan aspal dapat digunakan sebagai lapisan penutup dalam konstruksi jalan, karena adanya beban kendaraan dan cuaca maka lapisan penutup tersebut harus dapat menjaga stabilitas jalan. Menurut Departemen Pekerjaan Umum (2010). Jenis aspal yang digunakan tergantung pada iklim, kepadatan lalu lintas dan jenis bangunan yang digunakan. Beton aspal terdiri dari beberapa bahan yang dicampur bersama. Adapun bahan penyusun aspal beton yaitu aspal, kerikil dan bahan pengisi.

Aspal merupakan campuran antara aspal dan bintumen, biasa disebut juga bintumen, karena komponen dasar utama aspal adalah bintumen. Aspal atau bitumen merupakan bahan viskoelastik berwarna coklat tua, sehingga jika dipanaskan cukup akan melunak dan meleleh, begitu pula sebaliknya.

Agregat atau material adalah bahan butiran yang keras dan padat, yang terdiri dari kerikil, batu kapur ,batu bulat, dengan pasir. Material digunakan sebagai campuran aspal untuk membentuk kombinasi aspal, mortar atau campuran aspal yang kohesif dan seimbang. [2]
Volume 3 No.2, Juni 2021

e-ISSN 2775-4529

p-ISSN 2775-8613
Bahan pelengkap (filler) merupakan bahan yang lolos ayakan No. 200 dengan berat maksimal $75 \%$. Bahan pelengkap (filler) terdiri dari debu kapur, abu layang, semen dan abu batu, serta harus kering dan bebas dari gumpalan dan zat pengganggu lainnya.

Peneliti sebelumnya yang meneliti tentang campuran AC-yaitu penggunaan agregat batu sungai Wanggar sebagi Campuran AC-WC dan AC-BC [3] batu Sungai Tiakka pada campuran AC$B C[4]$ dan penggunaan batu gunung Posi' Padang Balla dalam campuran AC-BC[5] .

\section{METODE}

Lokasi pengambilan material terletak di Gunung Tambolang', Kecamatan Rantepao, Kabupaten Toraja Utara, Lokasi penelitian dapat dilihat pada gambar 1.

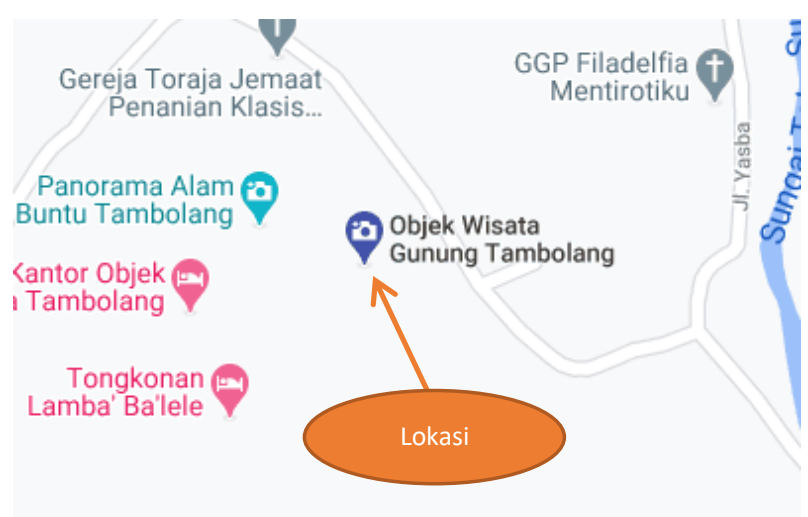

Gambar 1. Lokasi penelitian

\section{Pemeriksaan Karakteristik Material}

Pemeriksaan Analisis saringan adalah untuk memastikan persentase bobot butir total yang melewati satu saringan, kemudian menampilkan hasilkan persentase tersebut pada gambar grafik penguraian butir. Metode analisis saringan ini dimaksudkan sebagai pedoman untuk memeriksa dan menentukan sebaran butir (gradasi) agregat yang di saring. Tujuan dari pengujian ini adalah untuk mendapatkan persentase atau jumlah butir.

Pemeriksaan Keausan agregat merupakan Metode atau pedoman dengan menggunakan mesin LoS Angeles untuk mengetahui kekuatan material keausan agregat. Pengujian bertujuan untuk menentukan laju keausan, yang dinyatakan dengan rasio berat $(0,075 \mathrm{~mm})$ dari bahan tahan 
Paulus Civil Engineering Journal

Jurnal Teknik Sipil UKI-Paulus Makassar

https://doi.org/10.52722/pcej.v3i2.3214

aus yang melewati saringan No. 12 dengan berat aslinya.

Pemeriksaan berat jenis dan penyerapan material kasar dan halus. Maksud dari pemeriksaan ini adalah sebagai pedoman pemeriksaan untuk menentukan berat jenis permukaan jenuh, berat jenis curah, berat jenis semu terhadap material, serta angka penyerapan dari material. Pemeriksaan ini bertujuan untuk mendapatkan berat jenis permukaan jenuh, berat jenis curah dan berat jenis semu dan berat jenis semu serta besarnya angka penyerapan.

Pemeriksaan Nilai Setara Pasir/Sand Equivalent Test (SNI 03-4428-1997) Tujuan pemeriksaan ini adalah untuk mengetahui persentase kadar lumpur pada agregat.

Pemeriksaan Partikel Pipih dan Lonjong (ASTM D-4791-10) Bentuk partikel dari material adalah ukuran normal dari material, dengan ukuran nominalnya tergantung pada ukuran agregat utama dengan gradasi tertentu. Tes ini dirancang untuk menguji keseragaman agregat.

Pemeriksaan Kelekatan material terhadap Aspal (SNI 2439:2011) Tujuan dari pengujian ini adalah untuk mengetahui daya rekat material terhadap aspal. Kelekatan material ke aspal merupakan persentase dari total luas permukaan batuan yang tertutup aspal.

Pemeriksaan Berat Jenis Filler (ASTM C136:2012) Tujuan pemeriksaan ini adalah untuk mengetahui berat jenis filler yang digunakan sebagai bahan pelengkap campuran aspal. Uji berat jenis filler mengacu pada standar acuan SNI ASTM C136: 2012.

Pemeriksaan material Lolos Ayakan No.200/0,007mm (SNI ASTM C117 : 2012) Tujuan dari pengujian ini adalah untuk mengukur persentase material yang terkandung dalam material yang melewati saringan No. 200 sehingga dapat bermanfaat bagi perencana dan pelaksana konstruksi jalan.

\section{Standar Spesifikasi Bina Marga}

Pengujian karakteristik seperti pengujian kadar lumpur, pengujian material lolos saringan No.200, pengujian analisa saringan, dan pemeriksaan partikel pipih dan lonjong dapat dilakukan dengan cara melakukan pengujian ulang jika tidak memenuhi spesifikasi standar.
Volume 3 No.2, Juni 2021

e-ISSN 2775-4529

p-ISSN 2775-8613

Jika tidak memenuhi standar spesifikasi maka dapat langsung ke pembahasan dan analisis pemeriksaan keausan (abrasi) dengan mesin Los Angeles, pemeriksaan kerapatan curah dan penyerapan agregat kasar, pemeriksaan kerapatan curah penyerapan agregat halus dan pemeriksaan kelekatan material terhadap aspal.

\section{Rancangan dan Komposisi Campuran Untuk AC-BC}

Material yang digunakan dalam campuran aspal beton adalah material kasar (kerikil) dari Gunung Tambolang. Bahan pengikat (aspal dengan permeabilitas 60/70); dan bahan pengisi (filler) berasal dari semen. Digunakan pada campuran beton aspal, tujuannya adalah untuk mengisi rongga pada campuran beton aspal.

Komposisi campuran AC-BC yang digunakan adalah aspal campuran panas, yang mengandung agregat sebagai komponen campuran terbesar, dan pengikatnya adalah aspal, dimana pencampuran dilakukan dengan pemanasan.

Tabel 1. Rancangan komposisi campuran

\begin{tabular}{|c|c|c|c|}
\hline \multicolumn{2}{|c|}{ Ukuran Saringan } & \multirow{2}{*}{$\begin{array}{c}\text { Spesifikasi } \\
\text { BM } 2018 \\
(\%)\end{array}$} & \multirow{2}{*}{$\begin{array}{c}\text { Gradasi } \\
\text { Rancangan } \\
(\%)\end{array}$} \\
\hline Inchi & $\mathrm{Mm}$ & & \\
\hline $3 / 4 "$ & 19,000 & 100 & 100 \\
\hline 1/2" & 12,000 & $90-100$ & 95,00 \\
\hline 3/8" & 9,500 & $77-90$ & 83,50 \\
\hline No.4 & 4,750 & $53-69$ & 61,00 \\
\hline No.8 & 2,360 & $33-53$ & 43,00 \\
\hline No.16 & 1,180 & $21-40$ & 30,50 \\
\hline No.30 & 0,600 & $14-30$ & 22,00 \\
\hline No.50 & 0,300 & 9-Dec & 15,50 \\
\hline No.100 & 0,150 & $6-15$ & 10,50 \\
\hline No.200 & 0,075 & 4.- -9 & 6,50 \\
\hline
\end{tabular}

Setelah semua material yang diperlukan telah lolos pengujian, maka langkah selanjutnya adalah menguji jumlah benda dan menyiapkan bahan campuran (mix design) sesuai dengan komposisi campuran yang didapat.

Perhitungan estimasi awal kandungan aspal:

Kandungan aspal efektif minimal $=0,6 \%$ Kandungan aspal efektif maksimum $=1,2 \%$ Lolos saringan No. $200=6 \%$ Kandungan aspal desain maksimal $=10 \%$ Kandungan aspal rancangan $\min =5 \%$ 
Kemudian desain kandungan aspal untuk campuran minimal 5\%, 5,5\%,6\%,6,5\%, dan $7 \%$.

Berdasarkan perhitungan perkiraan awal kandungan aspal dari gabungan gradasi agregat tersebut di atas, Tabel 2 menunjukkan komposisi campuran dan proporsi bahan pengisi.

Tabel 2. Komposisi campuran

\begin{tabular}{|c|c|c|c|c|c|c|}
\hline \multirow{2}{*}{ Material } & \multirow{2}{*}{ Uk.Saringan } & \multicolumn{5}{|c|}{ Kadar Aspal } \\
\hline & & $5,00 \%$ & $5,50 \%$ & $6,00 \%$ & $6,50 \%$ & $7,00 \%$ \\
\hline \multirow{4}{*}{ Agregat Kasar } & 3/4" & & & & & \\
\hline & 1/2" & 4318 & 4300 & 4228 & 4264 & 4245 \\
\hline & 3/8" & 40,10 & 4,00 & & & \\
\hline & No.4 & & & & & \\
\hline \multirow{6}{*}{ Agregat Halus } & No.8 & \multirow{6}{*}{46,27} & \multirow{6}{*}{46,00} & \multirow{6}{*}{45,73} & \multirow{6}{*}{45,45} & \multirow{6}{*}{45,18} \\
\hline & No.18 & & & & & \\
\hline & No.30 & & & & & \\
\hline & No.50 & & & & & \\
\hline & No.100 & & & & & \\
\hline & No.200 & & & & & \\
\hline
\end{tabular}

\begin{tabular}{ccc}
\hline \multicolumn{2}{c}{ Filler } & 5,55 \\
\hline \multicolumn{2}{c}{ Tabel 3. Jumlah benda uji } & \\
\hline Kadar Aspal & $\begin{array}{c}\text { Marshall } \\
\text { Konvensional }\end{array}$ & $\begin{array}{c}\text { Marshall } \\
\text { Immersion }\end{array}$ \\
\hline $5,50 \%$ & 3 & \\
$6,00 \%$ & 3 & \\
$6,50 \%$ & 3 & 3 \\
$7,00 \%$ & 3 & \\
$7,50 \%$ & 3 & \\
\hline
\end{tabular}

\section{Pengujian Marshall Konvensional Campuran AC-BC}

Metode Marshall konvensional adalah memeriksa kestabilan dan laju alir, analisa densitas dan pori dari campuran padat yang terbentuk.

\section{Penentuan Kadar aspal optimum Campuran AC-BC}

Nilai kadar aspal optimal ditentukan sebagai nilai tengah dari kadar aspal maksimum dan kisaran kadar aspal minimum, yang juga memenuhi persyaratan lain, seperti VIM, laju aliran, dan lainlain. stabilitas yang tinggi dan flow yang rendah digunakan sebagai kadar aspal optimal (KAO).

\section{Pengujian Marshall Immersion Campuran AC-BC}

Pengujian ini untuk mengetahui ketahanan campuran aspal. Dalam pengujian ini, kinerja campuran diukur dalam air panas pada suhu $60^{\circ}$ C selama 30 menit dan 24 jam. Hal ini menunjukkan bahwa campuran tersebut sangat $\begin{array}{cccc}5,50 & 5,45 & 5,41 & 5,36 \\ \text { peka terhadap air dan suhu. Nilai tersebut diwakili }\end{array}$ oleh nilai kestabilan sisa yang merepresentasikan sifat kental antara agregat dan aspal dalam campuran.

\section{HASIL DAN PEMBAHASAN}

\section{Karakteristik Material \\ a. Material}

Berikut ini merupakan hasil dari pemeriksaan material kasar dan halus..

Berdasarkan hasil uji keausan material menggunakan peralatan aus Los Angeles diperoleh nilai ketahanan aus material kasar dari bagian $A$ sebesar $7 \%$, bagian $B$ sebesar $6,6 \%$, bagian $C$ sebesar $5,9 \%$, dan bagian $D$ sebesar $4,36 \%$. Dari semua hasil pemeriksaan, masingmasing nilai memenuhi syarat spesifikasi umum Bina Marga 2018, dengan maksimal 40\%. Oleh karena itu, terlihat bahwa akibat adanya gesekan antara agregat dan agregat atau antara agregat dengan roda maka agregat dari Gunung Tambolang dapat digunakan sebagai material lapisan permukaan jalan.

Berdasarkan hasil pemeriksaan penyerapan agregat kasar dan berat jenis yang memakai dua benda uji , didapatkan nilai untuk Berat Jenis Bulk sebesar 2,62, berat jenis SSD sebesar 2,66, berat jenis semu sebesar 2,72, dan Penyerapan Air sebesar $1,36 \%$. Keseluruan hasil pemeriksaan memenuhi syarat yang telah di tetapkan oleh Spesifikasi Umum Bina Marga 2018, yaitu untuk 
Paulus Civil Engineering Journal

Jurnal Teknik Sipil UKI-Paulus Makassar

https://doi.org/10.52722/pcej.v3i2.3214

Berat Jenis Bulk, SSD dan Semu yaitu minimal 2,5 dan Penyerapan Air maksimal 3\% atau penyerapan agregatnya kecil.

Berdasarkan hasil pemeriksaan Berat Jenis dan Penyerapan material Halus, didapatkan nilai untuk Berat Jenis Bulk sebesar 2,54, Berat Jenis SSD sebesar 2,55, Berat Jenis Semu sebesar 2,56 dan Penyerapan Air sebesar 2,58\%. Dari hasil pemeriksaan didapat hasil 2,5 minmal dan maksimal 3\% pada penyerapan air.

Gambar 2 di bawah ini merupakan hasil pemeriksaan analisa saringan.

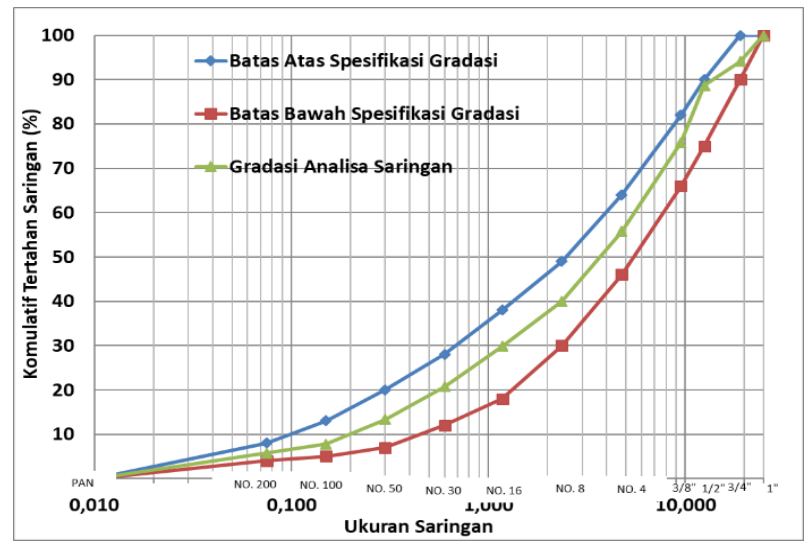

Gambar 2. Hasil pemeriksaan analisa saringan

Gambar grafik menunjukkan bahwa hasil analisis ayakan berupa gradasi agregat dan spesifikasinya dimana gradasi material pada batas atas dan batas bawah berada di antara (mendekati batas atas menunjukkan Gradasi agregat lebih halus) ini membuktikan bahwa material yang berada di Gunung Tambolang, memenuhi Spesifikasi Umum Bina Marga 2018.

Berdasarkan hasil pemeriksaan material lolos saringan No. 200 dengan nilai 6,2\%, memenuhi Spesifikasi Umum Bina Marga 2018 dengan nilai maksimal $10 \%$. Terlihat tidak adanya lempung atau lanau pada agregat Gunung Tambolang di Kabupaten Toraja Utara.

Hasil pengujian kadar lumpur dapat dilihat dari hasil pemeriksaan kadar lumpur dengan menggunakan dua sampel, hasil rata-rata nilai setara pasir (SE) sebesar 97,337\%, dan kadar lumpur sebesar 2,663\%. Keduanya memenuhi spesifikasi umum Bina Marga 2018 yaitu Sand Equivalen minimal $60 \%$ dan kadar lumpur maksimal $5 \%$.

pemeriksaan Partikel Kepipihan dan Kelonjongan Agregat Kasar . Dari hasil pengujian partikel pipih
Volume 3 No.2, Juni 2021

e-ISSN 2775-4529

p-ISSN 2775-8613 dan lonjong agregat kasar didapatkan partikel pipih yaitu 4,07\%, 3,71\%, 4,74\%, dan 0\%.Partikel lonjong yaitu $4,75 \%, 4,43 \%, 3,34 \%$ dan $0 \%$. Keduanya telah memenuhi syarat yaitu maksimal $10 \%$.

Pemeriksaan Kelekatan Agregat pada Aspal dapat diketahui bahwa sifat aspal hanya berupa visualisasi dan tidak harus melalui proses perhitungan. Tingkat kelengketan ditentukan berdasarkan luas permukaan sampel yang dilapisi aspal (kurang dari $95 \%$ atau lebih besar dari 95\%). Berdasarkan pengamatan dapat disimpulkan bahwa aspal dapat merekat dengan baik pada agregat.

\section{b. Analisis Aspal}

Berdasarkan hasil pengujian penetrasi didapatkan nilai penetrasi yaitu $66.7 \mathrm{~mm}$. Hasil pengujian memenuhi Spesifikasi Umum 2018 , yaitu minimal $60 \mathrm{~mm}$ - maksimal $70 \mathrm{~mm}$.

Berdasarkan hasil uji diperoleh nilai rata-rata 150 $\mathrm{cm}$. Hasil tersebut termasuk dalam persyaratan yang ditentukan dalam Spesifikasi Umum 2018 Direktorat Jenderal Bina Marga Kementerian Pekerjaan Umum dan Perumahan Rakyat, yaitu $\geq 100 \mathrm{~cm}$.

Berdasarkan hasil pengujian, rata-rata titik lembek aspal adalah 50,2 ${ }^{\circ}$ C. Hasil tersebut termasuk dalam persyaratan yang ditentukan dalam Spesifikasi Umum 2018 Direktorat Jenderal Bina Marga Kementerian Pekerjaan Umum dan Perumahan Rakyat, yaitu $\geq 48^{\circ} \mathrm{C}$.

Pada pengujian titik nyala didapatkan nilai ratarata $2900^{\circ}$ C. Hasil ini termasuk dalam persyaratan yang ditentukan dalam Spesifikasi Umum 2018 Direktorat Jenderal Bina Marga Kementerian Pekerjaan Umum dan Perumahan Rakyat, yaitu $\geq 2320 \mathrm{C}$

Nilai rata-rata $1.015 \mathrm{gr} / \mathrm{cc}$ diperoleh dari hasil uji berat jenis aspal. Hasil ini termasuk dalam persyaratan yang ditentukan dalam Spesifikasi Umum 2018 Direktorat Jenderal Bina Marga Kementerian Pekerjaan Umum dan Perumahan Rakyat, yaitu $\geq 1$.

Nilai rata-rata $0,434 \%$ diperoleh dari pengujian berat yang hilang. Hasil ini termasuk dalam persyaratan yang ditetapkan dalam Spesifikasi Umum 2018 Direktorat Jenderal Bina Marga 
Kementerian Pekerjaan Umum dan Perumahan Rakyat, yaitu $\geq 0,8 \%$.

Dari hasil uji penetrasi dengan TFOT diperoleh berat aspal rata-rata $84,7 \%$. Hasil ini masuk dalam persyaratan yang ditetapkan dalam Spesifikasi Umum 2018 Direktorat Jenderal Bina Marga Kementerian Pekerjaan Umum dan Perumahan Rakyat, yaitu $\geq 54 \%$.

\section{Marshall Konvensional}

Pembuatan sampel Kadar aspal untuk campuran AC-BC yaitu: 5,00\%, 5.5\%, 6,00\%, 6,5\%, 7,00\%. Didapatkan hasil bulk spesific gravity dan effective spesific gravity dapat dilihat pada Tabel 4 .

Tabel 4. Bulk Spesific Gravity dan Effective Spesific Gravity.

\begin{tabular}{cccccc}
\hline Nilai & \multicolumn{3}{l}{ Kadar Aspal (\%) } & & \\
\cline { 2 - 5 } & 5,00 & 5,50 & 6,00 & 6,50 & 7,00 \\
\hline Bulk Spesific Gravity & 2,74 & 2,76 & 2,77 & 2,79 & 2,80 \\
Bulk Spesific Gravity & 2,78 & 2,79 & 2,81 & 2,82 & 2,84 \\
\hline
\end{tabular}

Hasil pemeriksaan karakteristik Marshall in Mix), Flow, VMA (Void in Mineral Aggregate), konvensional yang meliputi Stabilitas, VIM (Void

VFB dapat dilinat pada tabel 5

Tabel 5.

Nilai Karakteristik marshall konvensional

\begin{tabular}{cccccc}
\hline \multirow{3}{*}{ Kadar Aspal (\%) } & \multicolumn{5}{c}{ Karakteristik Marshall Konvensional dan Penyerapan } \\
\cline { 2 - 6 } & $3-5(\%)$ & Min $800(\mathrm{~kg})$ & Min 65 $(\%)$ & $2-4(\mathrm{~mm})$ & Min 14 $(\%)$ \\
\cline { 2 - 6 } & VIM & Stabilitas & VFB & Flow & VMA \\
\hline 5.00 & 4,65 & 1347,31 & 70,15 & 3,10 & 15,59 \\
5.50 & 4,32 & 1581,62 & 73,76 & 2,75 & 16,47 \\
6.00 & 3,98 & 1933,10 & 77,04 & 2,55 & 17,34 \\
6.50 & 3,92 & 1523,05 & 78,74 & 2,95 & 18,45 \\
7.00 & 3,42 & 1171,57 & 82,18 & 3,45 & 19,18 \\
\hline
\end{tabular}

\section{a. VIM ( Void in Mix)}

Gambar berikut ini merupakan hasil yang di dapat dari pengujian analisis terhadap VIM.

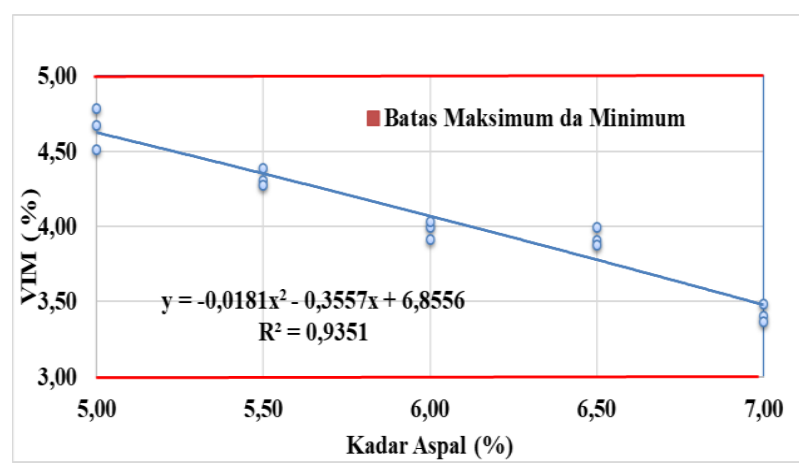

Gambar.3. Hubungan VIM dengan kadar aspal

Dapat dilihat dari Gambar 3 bahwa dengan menggunakan kadar aspal $5,00 \%-7,00 \%$ AC-BC dapat diperoleh VIM 3,42\% $-4,65 \%$ (rongga yang tidak terisi aspal pada campuran) dapat diperoleh. Semua memenuhi persyaratan kandungan aspal. Jadi dapat disimpulkan bahwa pengunan aspal dalam jumlah besar dapat membantu mengisi rongga pada campuran aspal.

\section{b. Stabilitas}

Dengan menggunakan kadar aspal 5,00\% $-7,00 \%$ diperoleh nilai stabilitas $1171.57 \mathrm{~kg}-1933.10 \mathrm{~kg}$. keseluruhan nilai stabilitas AC-BC memenuhi spesifikasi yang ditetapkan oleh Biro Penelitian dan Pengembangan Kementerian Pekerjaan Umum tahun 2018. Berdasarkan Gambar 4 maka disimpulkan bahwa penggunaan sedikit campuran aspal pada AC-BC akan menyebabkan lapisan aspal pada permukaan agregat menjadi lebih tipis, sehingga menimbulkan efek interlocking yang lebih lemah, sehingga mengurangi stabilitas lapisan. campuran, tetapi jika aspal meningkat lagi, gaya ikat antar material akan menjadi lebih kuat atau stabilitas campuran akan meningkat. Kemudian jika bitumen bertambah banyak maka lapisan penutup bitumen menjadi lebih tebal, yang akan menyebabkan ikatan antar agregat atau stabilitas campuran AC-BC menurun kembali. 
Paulus Civil Engineering Journal Jurnal Teknik Sipil UKI-Paulus Makassar https://doi.org/10.52722/pcej.v3i2.3214

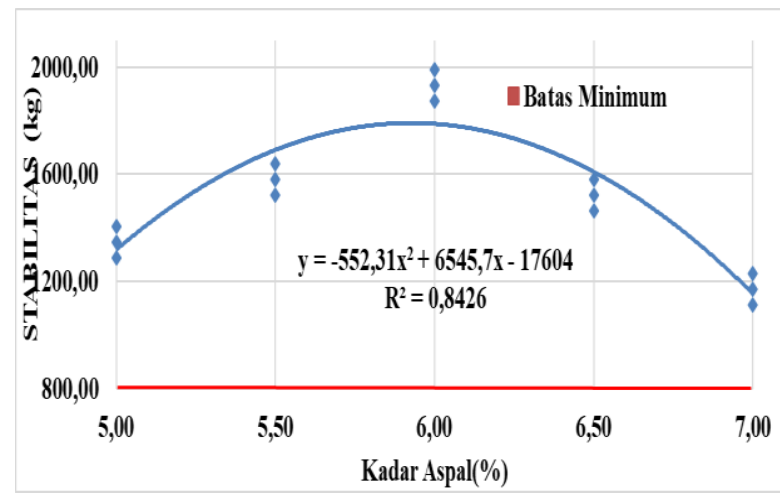

Gambar 4. Hubungan stabilitas dan kadar aspal

c. VFB

Berikut ini adalah hasih analisis terhadap VFB seperti yang terdapat pada gambar 5 .

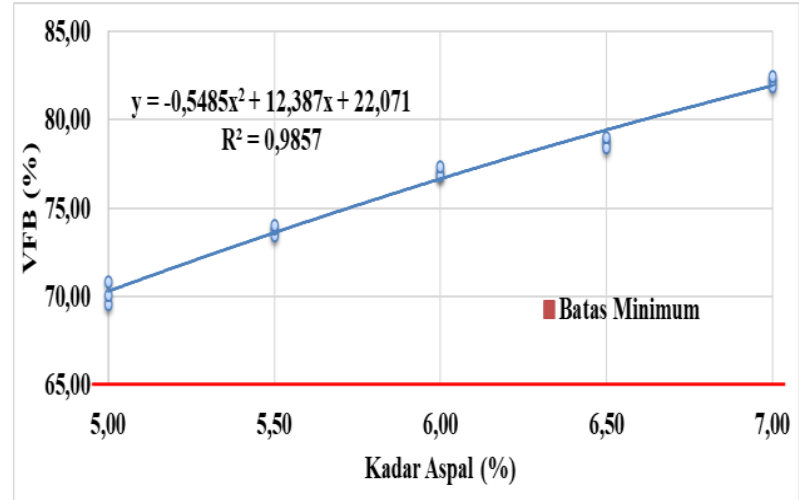

Gambar 5. Hubungan antara VFB dengan kadar aspal

Dapat dilihat pada penggunaan kadar aspal 5,00\% - 7,00\% untuk AC-BC didapatkan hasil VFB antara $70,15 \%-82,18 \%$. Nilai VFB semua kadar aspal untuk AC-BC memenuhi syarat yang telah ditetapkan oleh Badan Penelitian dan Pengembangan Departemen Pekerjaan Umum Tahun 2018. Dari Gambar 5 dapat disimpulkan bahwa penggunaan kadar aspal rendah menurunkan VFB, menggunakan kadar aspal yang mengalikan VFB, begitu pula sebaliknya. Dimana aspal akan mengisi semua rongga pada campuran dan agregat.

\section{d. Flow}

Berikut ini adalah hasil yang didapat pada analisis Flow seperti yang terdapat pada Gambar 6 .

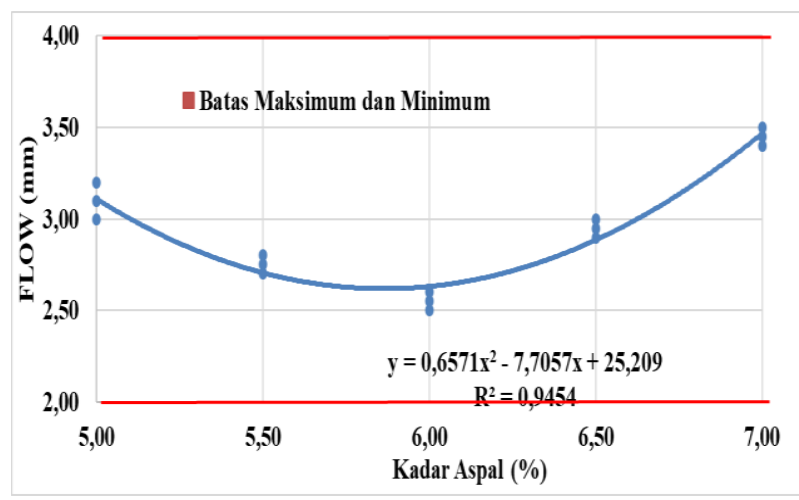

Gambar 6. Hubungan antara flow dengan kadar aspal

Dapat dilihat pada gambar bahwa pada kadar aspal 5,00\% $-7,00 \%$ nilai alirannya antara 2,55 $\mathrm{mm}-3,45 \mathrm{~mm}$. Semua nilai aliran dengan kadar aspal 5,00\% $-7,00 \%$ memenuhi persyaratan yang dikeluarkan oleh Badan Penelitian dan Pengembangan Kementerian Pekerjaan Umum pada tahun 2018. Kesimpulan yang diambil dari Gambar 6 adalah bahwa jika campuran aspal BC digunakan pada $A C$ dengan kandungan rendah, ikatan antar agregat berkurang, sehingga menghasilkan fleksibilitas yang lebih tinggi. Namun jika jumlah aspal yang digunakan bertambah maka gaya ikat antar agregat dalam campuran akan meningkat sehingga terjadi penurunan kelenturan campuran; kemudian jika jumlah aspal yang digunakan ditambah lagi maka lapisan penutup aspal tersebut akan menjadi lebih tebal, mengakibatkan Kekuatan campuran berkurang, tetapi kelenturannya lebih besar, yang artinya kekuatan atau kestabilan campuran akan berbanding terbalik dengan kelenturan campuran atau flow.

\section{e. VMA (Void in Mineral Aggregate)}

Penggunaan kadar aspal adalah 5,00\% $-7,00 \%$. untuk AC-BC diperoleh nilai VMA antara $15,59 \%$ $19,18 \%$. Tingkat aspal secara keseluruhan memenuhi standar yang ditetapkan oleh Badan Penelitian dan Pengembangan Kementerian Pekerjaan Umum pada tahun 2018. Hal ini dipengaruhi oleh peningkatan penggunaan aspal, karena fungsi aspal tidak hanya sebagai penutup agregat (aspal efektif) tetapi juga berfungsi untuk mengisi kekosongan antara partikel agregat dan agregat. . Dari Gambar 7 dapat disimpulkan bahwa semakin besar penggunaan aspal maka semakin besar rongga pada agregat yang terisi aspal sehingga nilai VMA akan semakin meningkat. Hal 
ini dipengaruhi oleh penggunaan aspal yang banyak, dimana pada saat pencampuran dan pemadatan aspal akan menutupi agregat, mengisi rongga antar agregat dan mengisi rongga pada agregat tersebut.

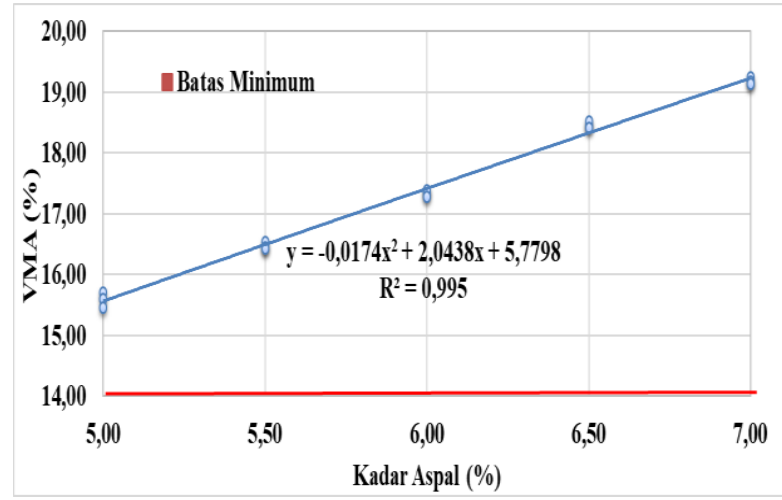

Gambar 7. Hubungan antara VMA dengan kadar aspal
Berdasarkan hasil analisis uji Marshall dapat diketahui karakteristik campuran AC-BC, dan kandungan aspal aktual pada campuran beton aspal dapat ditentukan yaitu kandungan aspal yang memenuhi semua standar atau karakteristik campuran Marshall dan aspal aktual adalah $5,00 \%$ dari kisaran kadar aspal AC-BC- 7,00\%. Namun, untuk kadar bitumen terbaik dipilih campuran AC-BC dengan kestabilan tertinggi, yaitu kadar bitumen $6,00 \%$.

\section{Stabilitas Marshall Sisa}

Setelah dilakukan pemeriksaan kadar aspal optimal, maka di lanjutkan pada pembuatan sampel berdasarkan kandungan aspal optimal, yaitu $6,00 \%$ untuk AC-BC lalu direndam selama \pm 24 jam pada suhu $\pm 60^{\circ} \mathrm{C}$. Dapatkan nilai stabilitas sisa Marshall dari campuran tersebut

\section{Penentuan Kadar Aspal Optimum}

Tabel 6. Hasil pengujian stabilitas marshall sisa

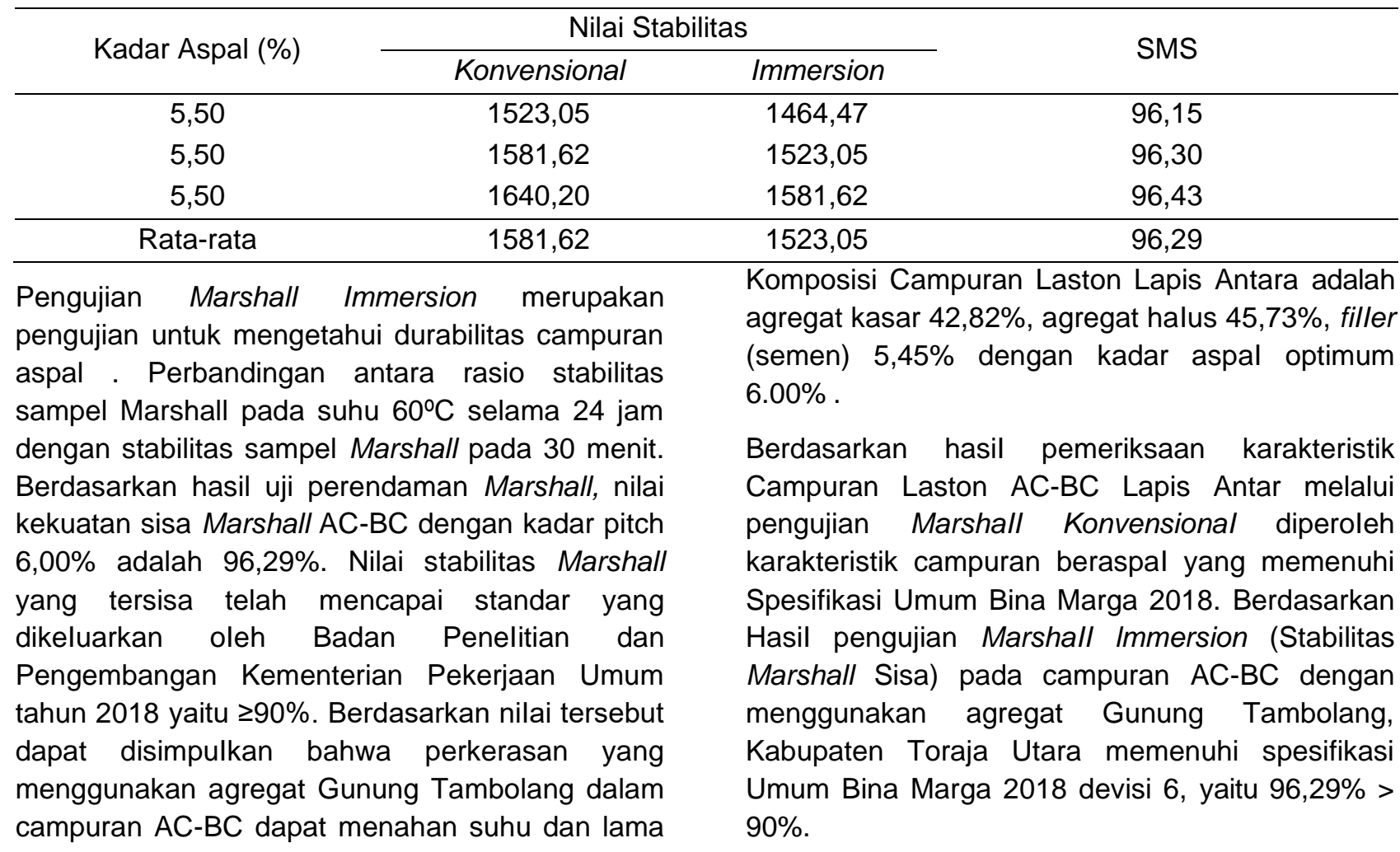
perendaman dalam air.

\section{KESIMPULAN}

Karakteristik material yang diambil dari Gunung Tambolang Toraja Utara, serta aspal penetrasi 60/70 dan berat jenis filler untuk Campuran AC-BC memenuhi Spesifikasi Umum Bina Marga 2018.

\section{DAFTAR PUSTAKA}

[1] Fani.L.A Irianto, Alpius, dan Elizabeth, 2019. "Pemanfatan Agregat Sungai Wanggar Kabupaten Nablre Sebagai Bahan Campuran AC-WC dan AC - BC". Paulus Civil 
Engineering Journal, Volume 1 Nomor 2. HIm 28-36.

[2] Direktorat Jenderal Bina Marga2018, Badan Penelitian Dan Pengembangan, Makassar: Departemen Pekerjaan Umum.

[3] Irene Sion Kondo Sosang, Alpius, Elizabeth, 2020. "Pemanfaatan Agregat Sungai Mawa Kecamatan Cendana dalam Campuran ACWC'. Paulus Civil Engineering Journal, Volume 1 Nomor 1. HIm 53-57.

[4] Direktorat Jenderal Bina Marga 2018, Spesifikasi Umum Bina Marga 2018 untuk Pekerjaan Konstruksi Jalan dan Jembatan., Jakarta: Kementrian Pekerjaan Umum dan Perumahan Rakyat.

[5] Laboratorium Aspal 2018. "Panduan Praktikum Jalan dan Aspal Teknik Sipil," Universitas Kristen Indonesia Paulus Makassar.

[6] Rachman, 2020. "Pemanfatan Batu Gunung Bottomale Toraja Utara sebagai campuran Iaston", J. Tek. sipil dan Teknol.. Volume. 6, Nomor.1, doi: https://doi.org/10.35308/jtsutu.v6i1.2307.

[7] Laboratorium Jalan dan Aspal 2018. Metode Pengujian Agregat, Makassar: Badan Penelitian dan Pengembangan Departemen Pekerjaan Umum.

[8] R. Rachman, 2019, "Karakteristik Campuran HRS - BASE Menggunakan Bubuk Dolomit Sebagai Filler," in Prosiding Konferensi
Nasional Teknik Sipil Ke-13 [KoNTekS-13], Banda Aceh.

[9] Irpan, R. Mangontan, dan Alpius (2020), "Pemanfaatan Batu Gunung Ambeso Pada Campuran AC-Base" Paulus Civil Engineering Journal. Volume.2, Nomor.1. HIm.58-62.

[10] Yudi, Angga, dan Alpius ,2019, "Karakteristik Campuran AC-WC dan AC-BC Menggunakan Bahan Tambah Serat ljuk" Paulus Civil Engineering Journal. Volume.1, No.2. HIm.18. DOI: https://doi.org/10.52722/pcej.v1i2.56

[11] R. Rachman, 2020, "The Effect of Immersion and Humidification toward Performance of Hot Rolled Asphalt Mixture," International Journal of Applied Engineering Research , vol. 15, nr. 5, pp. 503 - 509.

[12] Direktorat Jenderal Bina Marga 2018. Perkerasan Aspal Devisi 6, Jakarta: Bina Marga.

[13] S. Sukirman, 2003. Beton Aspal Campuran Panas, Edisi Kedua, Jakarta: Yayasan Obor.

[14] Sumardi, R. Rachman en J. Tanijaya, „Study of the Use Bagasse Ash as a Filler Replacement to Characteristics Asphalt Concrete," International Journal of Scientific Engineering and Science, vol. 3, nr. 8, pp. 6570, 2019 . 